\title{
Effects of Four Thinnings on the Growth, Yields and Financial Returns of a 62-Year-Old Red Pine Plantation
}

\author{
F. W. von Althen \\ Department of the Environment \\ Canadian Forestry Service \\ Great Lakes Forest Research Centre \\ Sault Ste. Marie, Ontario
}

\author{
W. M. Stiell \\ Department of the Environment \\ Canadian Forestry Service \\ Petawawa Forest Experiment Station \\ Chalk River, Ontario
}

and

R. B. Forster

Department of the Environment

Canadian Forestry Service

Forest Utilization Branch

Ottawa, Ontario

\begin{abstract}
Growth data for a 62-year old plantation of red pine (Pinus resinosa Ait.) at Rockland, Ontario, part of which was thinned four times between 1938 and 1972, and part of which was left unthinned, are presented for the two stand conditions, together with associated product yields and economic implications of alternative treatments. The investment in thinning, when based on historical costs and revenues, was attractive: the thinning program increased net present worth at each stage. When based on current costs and revenues, with no increase at an assumed inflation rate, the investment in thinning was less attractive, and it was not proved conclusively that the thinning program would be profitable. Financial growth peaked at a rotation age of approximately 50 years.
\end{abstract}

\section{Résumé}

Les auteurs présentent des données sur la croissance d'une plantation de Pin rouge (Pinus resinosa Ait.) âgée de 62 ans et sise à Rockland, Ontario. Une partie fut éclaircie quatre fois entre 1938 et 1972, une autre fut laissée intacte. Le rapport couvre ces deux conditions du peuplement outre les rendements connexes en produits et les implications économiques d'autres traitements. L'investissement dans les éclaircies, lorsque fondé sur des coûts et revenus historiques, s'avéra profitable: à chaque éclaircie la valeur nette actuelle augmenta. Mais lorsque fondé sur des coûts et revenus actuels, sans augmentation due à un taux assumé d'infla. tion, l'investissement dans les éclaircies était moins attrayant. et on ne pouvait prouver conclusivement qu'il serait profitable. La croissance financière cessa à l'âge de révolution d'environ 50 ans.

\section{Introduction}

The Rockland red pine (Pinus resinosa Ait.) plantation is one of the oldest managed plantations in Ontario and present stand conditions reflect the influence of one pruning and four thinning treatments. Six previous publications have described the plantation development from 1938 to 1961 (Sisam 1939; Mulloy 1943, 1946; Stiell 1953, 1957; von Althen and Stiell 1965), and this report summarizes the results to 1976. A brief review of the plantation history follows.

In 1914, 3-year-old seedlings were planted by hand, at $6 \times 6 \mathrm{ft}$ spacing, on 10 acres of abandoned pasture land near the village of Rockland, Ontario, 25 miles east of Ottawa. The plantation soil was a waterwashed till on the western portion of the area, changing to dry, interbanded sand and silt loam on the east. Site index based on the height of the dominant trees was 75 at 50 years from planting.
In 1938 the owner agreed to manage the plantation as a demonstration stand in cooperation with the Federal Forestry Branch, and two half-acre permanent sample plots were established (Fig. 1). Trees in one plot were pruned and thinned in that year, but the other plot was not treated then or subsequently. After the first pruning and thinning the managed stand was thinned again in 1951, 1961, and 1971 and both plots were remeasured in 1943, 1951, 1956, 1961, 1966, 1971, and 1976.

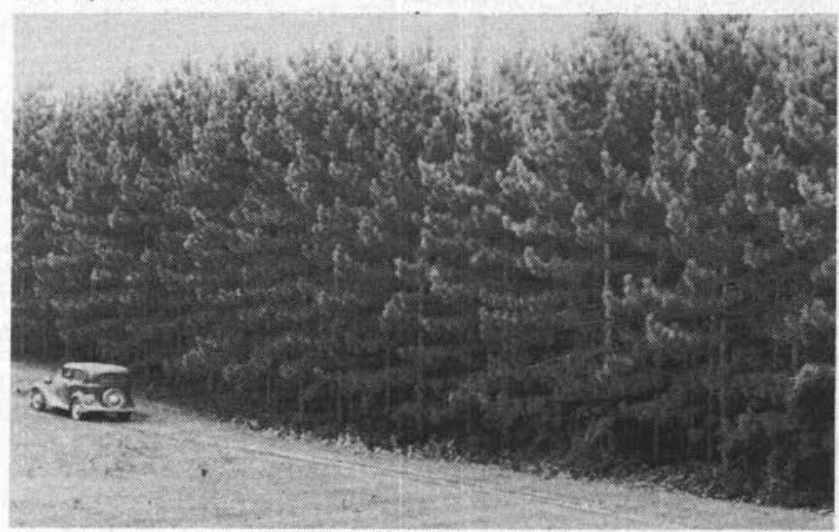

Fig. 1. Rockland plantation 1938.

\section{Stand Treatment}

\section{Thinning}

The first thinning in 1938 was relatively light as there was fear of windthrow and the material was too small to be sold for anything but fuelwood. Poorly formed and badly suppressed trees were marked for removal to provide more growing space for the most promising individuals and to leave a uniform stand with a well broken canopy. All marked trees were cut, branches were lopped, and the slash was burned, under the supervision of the owner.

In 1951 the canopy density and the shortness of the live crowns suggested the desirability of a second thinning, and the plantation was marked for removal of the smaller and suppressed trees and release of 160 designated crop trees per acre. This thinning, too, was carried out by a crew of men under the supervi- 
sion of the owner, who utilized most of the cut trees in his own sawmill.

After remeasurement of the plots in 1961, the plantation was marked for its third thinning. Marking was aimed at a further release of the 160 selected crop trees as well as the removal of unthrifty and suppressed trees which were not expected to survive the next decade. The thinning was started in the winter of 1961-1962 under the supervision of the owner, but was not completed owing to his poor health. Only 82 of the 128 trees marked for removal in the managed plot were actually cut.

The next thinning, which will probably be the last,

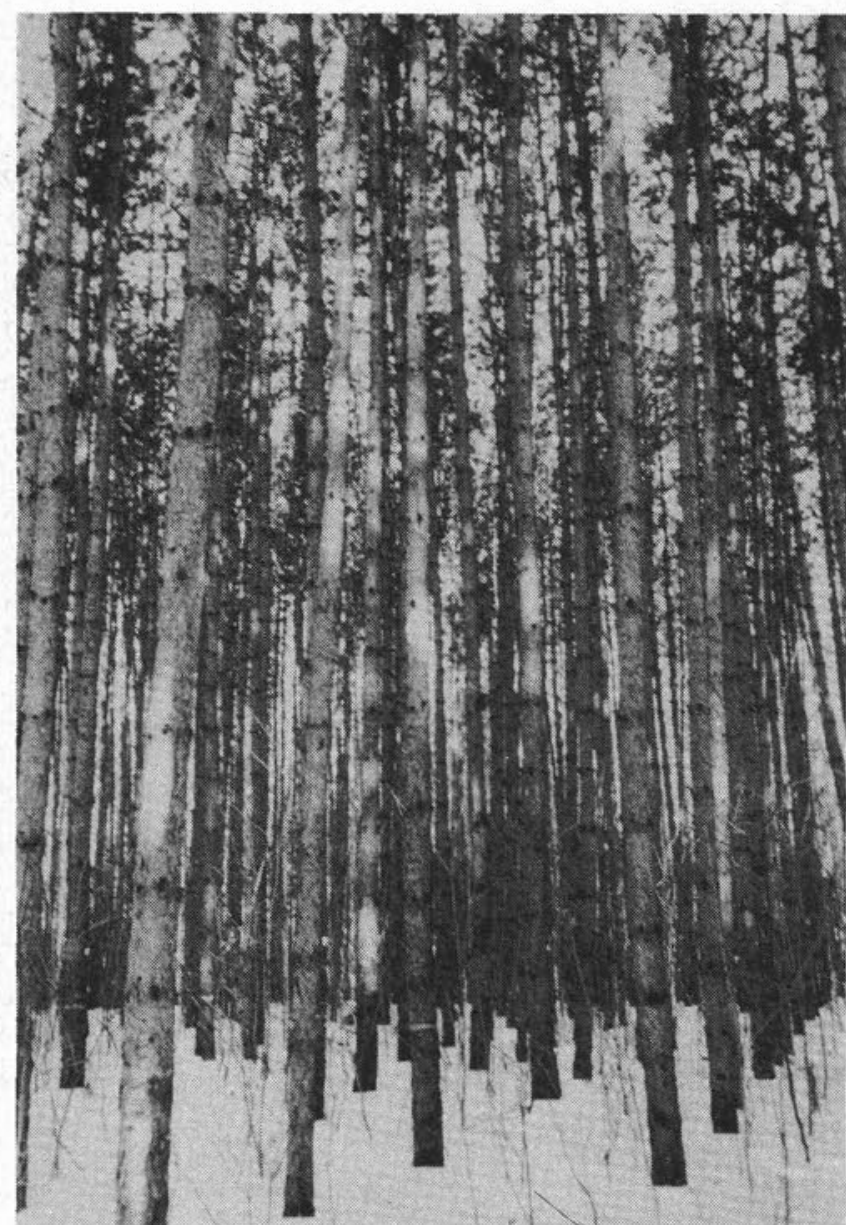

Fig. 2. Control plot in 1971 at age 57.

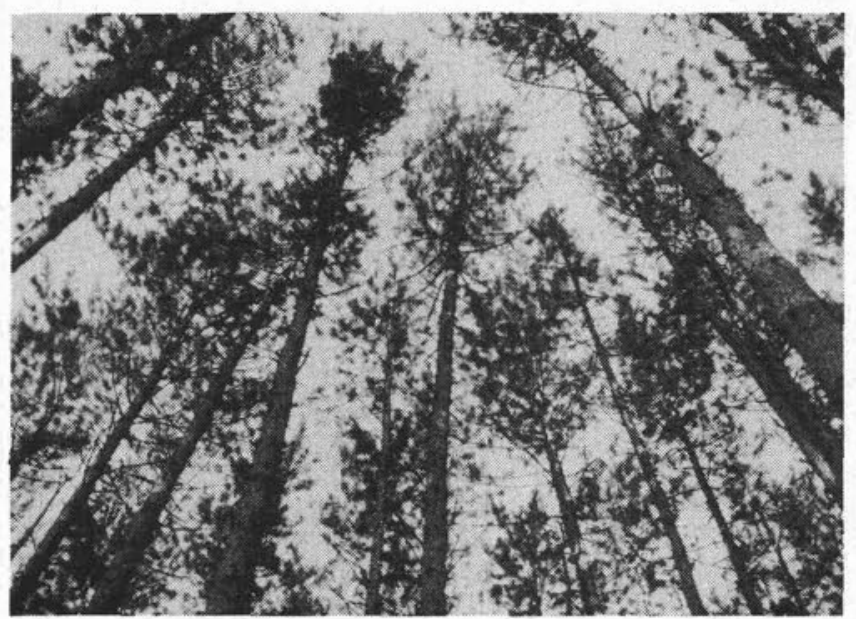

Fig. 3. Canopy density of control in 1971 at age 57. was carried out in the winter of 1971-1972, and removed all but the 160 designated crop trees per acre. The decision to apply a final thinning at this time was based on the density of the canopy which, of course, was partly the result of the unfinished logging in 1961. A further intermediate cut could have been made, but it was felt that the large, tall trees could be removed efficiently only by a large rubber-tired tractor. This required sufficient space to avoid damage to the residual trees. The thinning was carried out by a jobber who felled the trees with a power saw and skidded them full length to the landing with a wheeled skidder (Fig. 2-5).

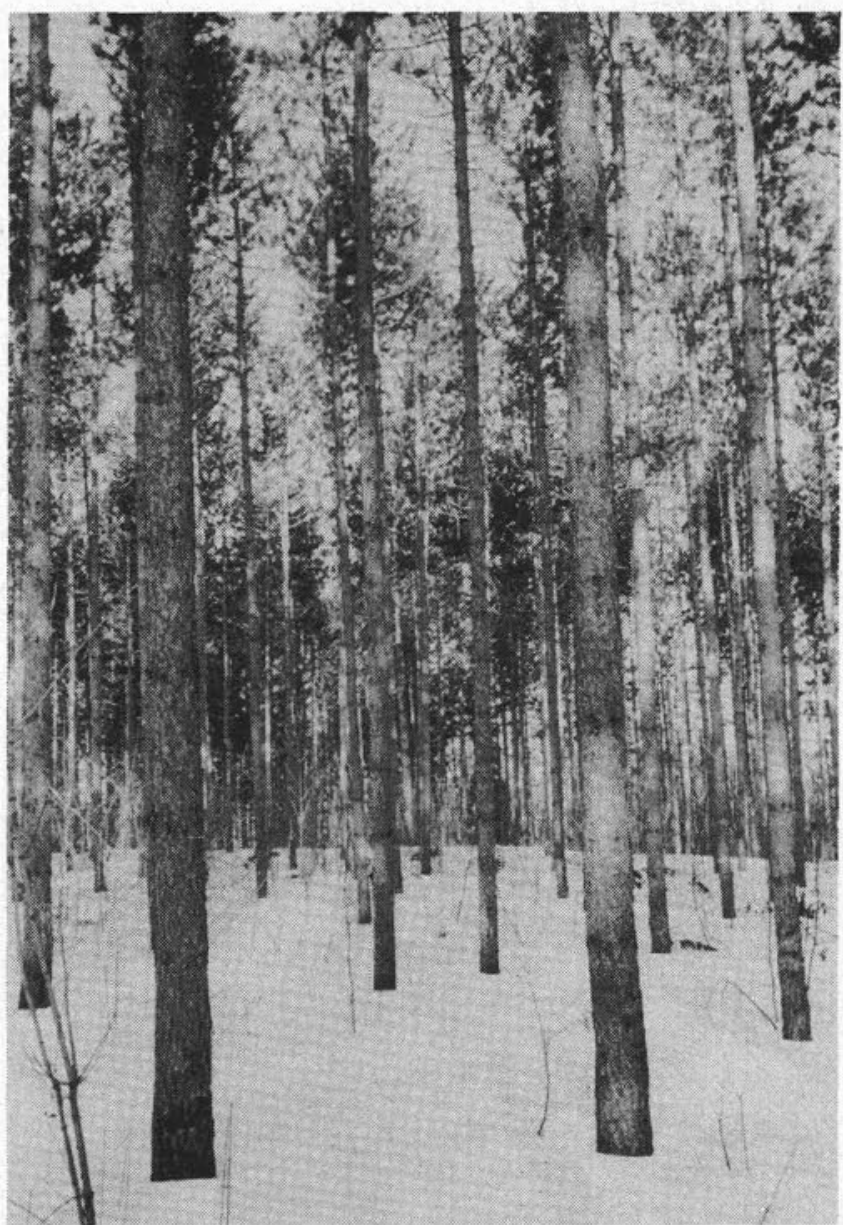

Fig. 4. Managed stand after thinning in 1971 at age 57.

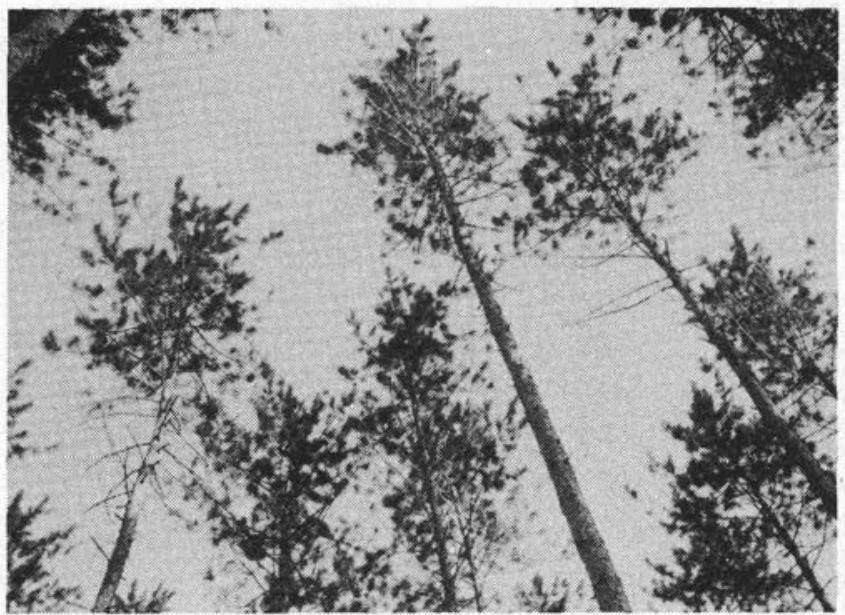

Fig. 5. Canopy density of managed stand after 1971 thinning at age 57 . 


\section{Pruning}

In 1938 all trees in the managed stand were pruned with saws to a height of $20 \mathrm{ft}$. This removed all dead branches and two or three whorls of living branches as well, leaving a live crown of approximately $50 \%$ of tree height. No trees were pruned in the control stand. Although better quality lumber could probably be sawn from the pruned trees, no stumpage premiums have been paid for them.

\section{Stand Development}

\section{Survival and Growth}

Growth data for the thinned and unthinned plots are shown in Table 1. The development of the respective plots is summarized below.

In the managed stand, thinning, together with natural mortality of 34 trees, increased average spacing from $6.9 \mathrm{ft}$ in 1938 to $16.6 \mathrm{ft}$ in 1976 . On the control plot, natural mortality of 464 trees $(48 \%$ of the 1938 stand) increased average spacing from $6.7 \mathrm{ft}$ to $9.2 \mathrm{ft}$. Mortality on the control plot has been restricted mainly to trees in the suppressed and intermediate crown classes.

In 1976, at 62 years from planting, the diameter of the tree of average basal area was 11.7 in. in the thinned stand and 9.0 in. in the control. Height growth was nearly identical in both plots: the average height of

Table 1. Summary of growth data per acre for the thinned stand and the control

\begin{tabular}{|c|c|c|c|c|c|c|c|c|c|c|c|}
\hline \multirow[b]{2}{*}{ Age } & \multirow[b]{2}{*}{ Year } & \multicolumn{2}{|c|}{ Number of trees } & \multicolumn{2}{|c|}{$\begin{array}{c}\text { Basal area } \\
\left(\mathbf{f t}^{2}\right)\end{array}$} & \multicolumn{2}{|c|}{$\begin{array}{c}\text { Total vol. } \\
\left(\mathrm{ft}^{3}\right)\end{array}$} & \multicolumn{2}{|c|}{$\begin{array}{l}\text { Merch, vol. } \\
\left(\mathbf{f} \mathbf{t}^{3}\right)^{f}\end{array}$} & \multicolumn{2}{|c|}{$\begin{array}{c}\text { Merch. vol. } \\
\text { (fbm)o }\end{array}$} \\
\hline & & Thinned & Control & Thinned & Control & Thinned & Control & Thinned & control & Thinned & Control \\
\hline \multirow[t]{3}{*}{24} & 1938 & & & & & & & & & & \\
\hline & $\begin{array}{l}\mathrm{BT}^{a} \\
\mathrm{~T}^{b}\end{array}$ & $\begin{array}{r}912 \\
322 \\
\end{array}$ & $\underline{976}$ & $\begin{array}{r}193 \\
53 \\
\end{array}$ & 201 & $\begin{array}{l}3681 \\
1000 \\
\end{array}$ & 3820 & $\begin{array}{r}2349 \\
488 \\
\end{array}$ & 2364 & $\begin{array}{r}1488 \\
90\end{array}$ & 2096 \\
\hline & $\mathrm{AT}^{\circ}$ & $\overline{590}$ & $\overline{976}$ & 140 & 201 & 2681 & 3820 & 1861 & 2364 & 1398 & 2096 \\
\hline \multirow[t]{2}{*}{29} & 1943 & & & & & & & & & & \\
\hline & $\begin{array}{l}\mathrm{BT}^{\mathrm{GPI}} \\
\mathrm{MP}^{0}\end{array}$ & $\frac{582}{8}$ & $\frac{884}{92}$ & $\begin{array}{r}157 \\
18 \\
1\end{array}$ & $\begin{array}{r}208 \\
20 \\
13\end{array}$ & $\begin{array}{r}3408 \\
752 \\
25\end{array}$ & $\begin{array}{r}4475 \\
896 \\
241\end{array}$ & $\begin{array}{r}2547 \\
703 \\
17\end{array}$ & $\begin{array}{r}3032 \\
676 \\
8\end{array}$ & $\begin{array}{r}5353 \\
3955 \\
0\end{array}$ & $\begin{array}{r}4366 \\
2270 \\
0\end{array}$ \\
\hline \multirow[t]{3}{*}{37} & 1951 & & & & & & & & & & \\
\hline & $\mathrm{T}_{\mathrm{T}}^{\mathrm{BT}}$ & $\begin{array}{l}566 \\
162 \\
\end{array}$ & 802 & $\begin{array}{r}184 \\
40\end{array}$ & $\underline{212}$ & $\begin{array}{l}4725 \\
1001\end{array}$ & 5366 & $\begin{array}{r}3825 \\
719\end{array}$ & 4059 & $\begin{array}{r}13406 \\
1422\end{array}$ & 9018 \\
\hline & $\begin{array}{l}\text { AT } \\
\text { GPI } \\
\text { M }\end{array}$ & $\frac{404}{16}$ & $\frac{802}{82}$ & $\begin{array}{r}144 \\
30 \\
3\end{array}$ & $\begin{array}{r}212 \\
17 \\
13\end{array}$ & $\begin{array}{r}3724 \\
1385 \\
68\end{array}$ & $\begin{array}{r}\overline{5366} \\
1179 \\
288\end{array}$ & $\begin{array}{r}\overline{3106} \\
1303 \\
25\end{array}$ & $\begin{array}{r}\overline{4059} \\
1178 \\
151\end{array}$ & $\begin{array}{c}11984 \\
8067 \\
25\end{array}$ & $\begin{array}{r}9018 \\
4652 \\
0\end{array}$ \\
\hline \multirow[t]{2}{*}{42} & 1956 & & & & & & & & & & \\
\hline & $\begin{array}{l}\text { BT } \\
\text { GPI } \\
\text { M }\end{array}$ & $\frac{404}{0}$ & $\frac{730}{72}$ & $\begin{array}{r}161 \\
17 \\
0\end{array}$ & $\begin{array}{r}216 \\
15 \\
11\end{array}$ & $\begin{array}{r}4609 \\
885 \\
0\end{array}$ & $\begin{array}{r}5949 \\
849 \\
266\end{array}$ & $\begin{array}{r}3925 \\
819 \\
0\end{array}$ & $\begin{array}{r}4702 \\
827 \\
184\end{array}$ & $\begin{array}{r}17963 \\
5979 \\
0\end{array}$ & $\begin{array}{r}13790 \\
4772 \\
0\end{array}$ \\
\hline \multirow[t]{3}{*}{47} & 1961 & & & & & & & & & & \\
\hline & ${ }_{\mathrm{T}}^{\mathrm{BT}}$ & $\begin{array}{r}400 \\
82\end{array}$ & 678 & $\begin{array}{r}179 \\
32\end{array}$ & 223 & $\begin{array}{r}5476 \\
968\end{array}$ & 6753 & $\begin{array}{r}4704 \\
816\end{array}$ & 5470 & $\begin{array}{r}23309 \\
3575\end{array}$ & 20250 \\
\hline & $\begin{array}{l}\text { AT } \\
\text { GPI } \\
\text { M }\end{array}$ & $\frac{318}{4}$ & $\frac{678}{52}$ & $\begin{array}{r}147 \\
19 \\
1\end{array}$ & $\begin{array}{r}223 \\
16 \\
9\end{array}$ & $\begin{array}{r}4508 \\
891 \\
24\end{array}$ & $\begin{array}{r}\overline{6753} \\
1047 \\
243\end{array}$ & $\begin{array}{r}3888 \\
798 \\
19\end{array}$ & $\begin{array}{r}\overline{5470} \\
937 \\
169\end{array}$ & $\begin{array}{r}\overline{19374} \\
5346 \\
0\end{array}$ & $\begin{array}{r}20250 \\
6460 \\
0\end{array}$ \\
\hline \multirow[t]{2}{*}{52} & 1966 & & & & & & & & & & \\
\hline & $\begin{array}{l}\text { BT } \\
\text { GPI } \\
\text { M }\end{array}$ & $\frac{318}{0}$ & $\frac{630}{48}$ & $\begin{array}{r}165 \\
18 \\
0\end{array}$ & $\begin{array}{r}231 \\
17 \\
9\end{array}$ & $\begin{array}{r}5457 \\
949 \\
0\end{array}$ & $\begin{array}{r}7380 \\
895 \\
268\end{array}$ & $\begin{array}{r}4770 \\
882 \\
0\end{array}$ & $\begin{array}{r}6173 \\
899 \\
196\end{array}$ & $\begin{array}{r}25711 \\
5977 \\
0\end{array}$ & $\begin{array}{r}26378 \\
6220 \\
92\end{array}$ \\
\hline \multirow[t]{3}{*}{57} & 1971 & & & & & & & & & & \\
\hline & $\stackrel{\mathrm{BT}}{\mathrm{T}}$ & $\begin{array}{l}314 \\
154 \\
\end{array}$ & 550 & $\begin{array}{r}180 \\
73 \\
\end{array}$ & 224 & $\begin{array}{l}6211 \\
2468 \\
\end{array}$ & 7625 & $\begin{array}{l}5405 \\
2113 \\
\end{array}$ & 6557 & $\begin{array}{l}30812 \\
11366 \\
\end{array}$ & 31228 \\
\hline & $\begin{array}{l}\text { AT } \\
\text { GPI } \\
\text { M }\end{array}$ & $\frac{160}{4}$ & $\overline{\frac{550}{80}}$ & $\begin{array}{r}107 \\
16 \\
1\end{array}$ & $\begin{array}{r}224 \\
11 \\
18\end{array}$ & $\begin{array}{r}3743 \\
791 \\
37\end{array}$ & $\begin{array}{r}7625 \\
783 \\
538\end{array}$ & $\begin{array}{r}3292 \\
665 \\
30\end{array}$ & $\begin{array}{r}6557 \\
795 \\
411\end{array}$ & $\begin{array}{r}\overline{19446} \\
5217 \\
116\end{array}$ & $\begin{array}{r}31228 \\
5094 \\
244\end{array}$ \\
\hline \multirow[t]{2}{*}{62} & 1976 & & & & & & & & & & \\
\hline & $\begin{array}{l}\text { BT } \\
\text { GPI } \\
\text { M }\end{array}$ & $\frac{158}{2}$ & $\frac{512}{38}$ & $\begin{array}{r}117 \\
11 \\
1\end{array}$ & $\begin{array}{r}227 \\
13 \\
10\end{array}$ & $\begin{array}{r}4291 \\
590 \\
42\end{array}$ & $\begin{array}{r}8175 \\
858 \\
308\end{array}$ & $\begin{array}{r}3839 \\
583 \\
36\end{array}$ & $\begin{array}{r}6942 \\
625 \\
240\end{array}$ & $\begin{array}{r}22612 \\
3378 \\
212\end{array}$ & $\begin{array}{r}35736 \\
4850 \\
342\end{array}$ \\
\hline
\end{tabular}

a) BT - Before thinning

b) T - Thinning

c) AT - After thinning

d) GPI - Gross periodic increment

e)M - Mortality

f)Trees 6 in. DBH and larger

${ }^{g}$ )Trees 8 in. DBH and larger 
dominant trees was $86 \mathrm{ft}$, and the maximum was $90 \mathrm{ft}$. In the control plot the maximum basal area of 231 $\mathrm{ft}^{2}$ per acre was reached at 52 years from planting. During the next 5 years natural mortality exceeded growth for a net loss of $7 \mathrm{ft}^{2}$. Basal area of the managed stand was reduced by the four thinnings to 70 , 68,60 and $48 \%$, respectively, of that of the control, and never rose above the $193 \mathrm{ft}^{3}$ per acre obtained in 1938.

Gross total volume production per acre was 9,924 and $10,327 \mathrm{ft}^{3}$, respectively, for the thinned stand and the control, but net total production per acre was $9,728 \mathrm{ft}^{3}$ for the thinned stand, and $8,175 \mathrm{ft}^{3}$ for the control.

Gross production was 39,418 and 36,414 fbm per acre, respectively, for the thinned stand and the control, while the corresponding net production was 39,065 and 35,736 fbm per acre, respectively.

These data confirm findings elsewhere that thinning can salvage mortality and thereby increase net yield, but it cannot increase the total $\mathrm{ft}^{3}$ production of a fully stocked stand. Total fbm volume on the control plot will more closely approach, but will not equal, that of the managed stand when 51 trees grow into the 8 -in. class. Despite its high rate of mortality the control plot remains very dense and contains a significant number of bent and leaning trees. This indicates increasing vulnerability to snow damage and associated risk in retaining the unthinned stand, notwithstanding its potential for ingrowth to sawlog sizes.

\section{Crop Trees}

Although all trees were pruned in the managed por- tion of this plantation, normally only 100 to 200 crop trees per acre are so treated. Since pruning is a costly investment on which interest charges must be carried for many years, it is important to know how many crop trees, selected at an early stand age, will be present in the final stand. In the managed portion of this plantation 200 crop trees per acre were selected in 1938. In 1951 this number was reduced to 160 trees. Of these 160 trees, 118 trees or $74 \%$ advanced into the final stand following the 1971 thinning. This shows that careful selection of potential crop trees and adherence to one thinning regime to promote their growth can guarantee the advancement of a high percentage of early selected crop trees into the final stand.

\section{Quality Products}

To evaluate the influence of the thinnings on tree size and quality development in this plantation, all trees in both plots were appraised in 1961 on the basis of size, stem straightness, and freedom from defects, for their possible utilization under different intensities of management. Under the most intensive management the order of preference was poles, sawlogs and pulpwood. All trees qualifying for poles were graded for size and length and were recorded in the appropriate pole classes (Anon. 1960). Trees with a $\mathrm{DBH}$ of $8 \mathrm{in}$. or more were recorded as sawlogs and merchantable volume was computed in $\mathrm{fbm}$ according to the International Rule (1/4). Small trees and tops of poles and sawlogs were classed as fuelwood or pulpwood and their volume was calculated on the basis of $85 \mathrm{ft}^{3}$ per cord.

Table 2. Merchantable volume per acre of the thinned stand and the control by three intensities of management and two types of cut.

\begin{tabular}{|c|c|c|c|c|c|c|c|c|c|c|c|c|c|}
\hline \multirow[b]{3}{*}{$\begin{array}{l}\text { Age of } \\
\text { stand }\end{array}$} & \multirow[b]{3}{*}{ Type of cut } & \multirow{2}{*}{\multicolumn{2}{|c|}{$\begin{array}{l}\text { Managed for pulp } \\
\text { Thinned Control }\end{array}$}} & \multicolumn{4}{|c|}{ Managed for sawlogs and pulp } & \multicolumn{6}{|c|}{ Managed for poles, sawlogs and pulp } \\
\hline & & & & \multicolumn{2}{|c|}{ Thinned } & \multicolumn{2}{|c|}{ Control } & \multicolumn{3}{|c|}{ Thinned } & \multicolumn{3}{|c|}{ Control } \\
\hline & & $\begin{array}{l}\text { Pulp } \\
\text { cords }\end{array}$ & $\begin{array}{l}\text { Pulp } \\
\text { cords }\end{array}$ & $\begin{array}{c}\text { Sawlogs } \\
\text { fbm }\end{array}$ & $\begin{array}{c}\text { Pulp } \\
\text { cords }\end{array}$ & $\begin{array}{c}\text { Sawlogs } \\
\text { fbm }\end{array}$ & $\begin{array}{l}\text { Pulp } \\
\text { cords }\end{array}$ & $\begin{array}{c}\text { Poles } \\
\mathrm{ft}^{3}\end{array}$ & $\begin{array}{c}\text { Sawlogs } \\
\text { fbm }\end{array}$ & $\begin{array}{l}\text { Pulp } \\
\text { cords }\end{array}$ & $\begin{array}{c}\text { Poles } \\
\mathrm{ft}^{3}\end{array}$ & $\begin{array}{c}\text { Sawlogs } \\
\text { fbm }\end{array}$ & $\begin{array}{c}\text { Pulp } \\
\text { cords }\end{array}$ \\
\hline 24 & $\begin{array}{l}\text { If clearcut } \\
\text { before } 1938 \\
\text { thinning }\end{array}$ & 27.6 & 27.8 & 1,488 & 23.2 & 2,096 & 21.2 & - & 1,488 & 23.2 & - & 2,096 & 21.2 \\
\hline 24 & Thinning & 5.7 & - & 90 & 5.5 & - & - & - & 90 & 5.5 & 一 & - & - \\
\hline 37 & $\begin{array}{l}\text { If clearcut } \\
\text { before } 1951 \\
\text { thinning }\end{array}$ & 45.0 & 47.8 & 13,406 & 12.1 & 9,018 & 25.2 & 1,308 & 5,960 & 15.6 & 992 & 7,310 & 18.9 \\
\hline 37 & Thinning & 8.5 & - & 1,422 & 4.9 & 一 & 一 & 352 & 715 & 2.6 & - & 一 & - \\
\hline 47 & $\begin{array}{l}\text { If clearcut } \\
\text { before } 1961 \\
\text { thinning }\end{array}$ & 55.3 & 6.44 & 23,309 & 3.0 & 20,250 & 18.3 & 2,959 & 4,415 & 10.1 & 2,669 & 7,165 & 16.1 \\
\hline 47 & Thinning & 9.6 & - & 3,575 & 1.5 & - & 一 & 427 & 796 & 2.8 & - & - & - \\
\hline 57 & $\begin{array}{l}\text { If clearcut } \\
\text { before } 1971 \\
\text { thinning }\end{array}$ & 63.6 & 71.1 & 30,812 & 0.9 & 31,228 & 10.3 & 3,105 & 7,992 & 11.7 & 2,858 & 10,582 & 21.4 \\
\hline 57 & Thinning & 24.9 & - & 11,366 & 0.9 & - & - & 1,081 & 2,996 & 5.7 & - & 一 & - \\
\hline 62 & $\begin{array}{l}\text { If clearcut } \\
\text { in } 1976\end{array}$ & 45.2 & 81.7 & 22,612 & 0.5 & 35,736 & 10.4 & 2,184 & 5,900 & 7.7 & 2,931 & 11,604 & 22.9 \\
\hline 62 & $\begin{array}{l}\text { Total utilization } \\
\text { to } 1976- \\
\text { standing volume } \\
\text { plus all thinnings }\end{array}$ & 93.9 & 81.7 & 39,065 & 13.3 & 35,736 & 10.4 & 4,044 & 10,497 & 24.3 & 2,931 & 11,604 & 22.9 \\
\hline
\end{tabular}


Since the trees were appraised for quality only in 1961 the calculation of merchantable volume in $\mathrm{ft}^{3}$ in 1951 and 1976 is based on the assumption that a tree acceptable as a pole in 1961 would also have been acceptable in 1951 and 1976 if of sufficient dimension (Anon. 1948). Determination of sawlog and pulpwood volume removed in thinnings in 1938 and 1951 is based on the percentage of these products in the 1961 thinning, and is adjusted for 1938 and 1951 height and diameter data.

Table 2 shows the comparative merchantable volume per acre, by three intensities of utilization, of all trees 6 in. $\mathrm{DBH}$ and larger, inclusive of thinnings, for the treatment dates and 1976.

\section{Economic Analysis}

\section{Historical Costs and Returns}

One method of assessing a series of alternatives economically is to compare their net present worth. The net present worth is the surplus or value of an alternative when all costs and benefits are discounted to a single point in time, usually the beginning of the investment period, at a pre-determined interest rate. There are many methods of economic analysis but net present worth was used because it is easy to calculate and relatively easy to understand.

To be able to compare alternatives of different durations of time, it was assumed that the land would remain in forest and that the costs and benefits accruing in the first rotation would be experienced in subse- quent rotations. Present worth computed in this analysis assumed a_continuing series of rotations.

The first step in analyzing an alternative is to determine or estimate all of the cash flows for the investment period. The actual or estimated per acre costs incurred in managing the Rockland plantation are shown in Table 3 ; the value of products used in the calculation of per acre revenue is shown in Table 4.

\section{Management Alternatives}

Costs and revenues were computed for the following hypothetical alternatives of plantation management: 1) planting during the initial year and clearcutting at stand age of $24,37,47,57$ and 62 years with no intermediate treatments; 2) planting during the initial year, making intermediate thinnings and clearcutting at stand age of $37,47,57$ or 62 years (Table 5 ). Five alternatives were computed with the thinned plot data and five with the control plot data, for a total of ten alternatives. Taxes and administration costs were not included in the calculations. The returns from the thinned stand are considered conservative since the greater unit value associated with larger sawlog sizes is not reflected in the economic analysis.

During the 24th year, pruning was carried out on the control plot at a cost of $\$ 10.00$ per acre. This pruning operation will allow production of clear lumber or veneer to a height of $20 \mathrm{ft}$ when the timber is harvested. Presumably a premium will be paid for the logs because of the improved quality. Since the

Table 3. Actual ${ }^{a}$ or estimated cost per acre

\begin{tabular}{|c|c|c|c|c|c|c|}
\hline Activity & 1914 & 1938 & 1951 & 1961 & 1971 & 1976 \\
\hline Planting...................... & $\$ 10.00$ & & & $\alpha=$ & & \\
\hline $\begin{array}{l}\text { Pruning } \ldots \ldots \ldots \ldots \ldots \ldots \ldots \ldots \ldots \ldots \ldots \ldots \\
\text { Thinning. } \ldots \ldots \ldots \ldots \ldots \ldots \ldots\end{array}$ & & $\begin{array}{r}\$ 10.00 \\
20.33\end{array}$ & $\$ 141.29$ & $\$ 240.00$ & $\$ 622.50$ & \\
\hline $\begin{array}{l}\text { Clearcut } \\
\quad \text { Control } \ldots \ldots \ldots \ldots \ldots \ldots \ldots \ldots \\
\text { Thinned } \ldots \ldots \ldots \ldots \ldots \ldots\end{array}$ & & $\begin{array}{l}66.62 \\
67.71\end{array}$ & $\begin{array}{l}542.94 \\
562.87\end{array}$ & $\begin{array}{l}1390.42 \\
1237.64\end{array}$ & $\begin{array}{l}1777.50 \\
1590.00\end{array}$ & $\begin{array}{r}\$ 2451.00 \\
1356.00\end{array}$ \\
\hline
\end{tabular}

a) LaBrecque, A. L. 1964. Costs and returns based on data of the Rockland red pine plantation. Economics Division, Canadian Forestry Service, Ottawa, Ont. (File report).

Table 4. Value of products used in the calculation of revenues $^{a}$

\begin{tabular}{|c|c|c|c|c|c|c|}
\hline \multirow[b]{2}{*}{ Product } & \multirow[b]{2}{*}{$\begin{array}{c}\text { Type of } \\
\text { cut }\end{array}$} & \multicolumn{5}{|c|}{ Age of stand (years of planting) } \\
\hline & & 24 & 37 & 47 & 57 & 62 \\
\hline & & $\$$ & $\$$ & $\$$ & $\$$ & $\$$ \\
\hline $\begin{array}{l}\text { Pulpwood } \\
\text { (cord) }\end{array}$ & $\begin{array}{l}\text { Thinning } \\
\text { Clearcut }\end{array}$ & $\begin{array}{l}2.00 \\
2.00\end{array}$ & $\begin{array}{l}12.00 \\
12.00\end{array}$ & $\begin{array}{l}18.00 \\
18.00\end{array}$ & $\begin{array}{l}24.00 \\
24.00\end{array}$ & 28.00 \\
\hline $\begin{array}{l}\text { Sawlogs } \\
\text { (Mfbm) }\end{array}$ & $\begin{array}{l}\text { Thinning } \\
\text { Clearcut }\end{array}$ & $\begin{array}{l}7.00 \\
7.00\end{array}$ & $\begin{array}{l}32.00 \\
35.00\end{array}$ & $\begin{array}{l}42.00 \\
45.00\end{array}$ & $\begin{array}{l}57.00 \\
60.00\end{array}$ & 85.00 \\
\hline $\begin{array}{l}\text { Poles } \\
\qquad\left(\mathrm{ft}^{3}\right)\end{array}$ & $\begin{array}{l}\text { Thinning } \\
\text { Clearcut }\end{array}$ & - & $\begin{array}{l}.37 \\
.39\end{array}$ & $\begin{array}{l}.52 \\
.54\end{array}$ & $\begin{array}{l}.68 \\
.70\end{array}$ & .78 \\
\hline
\end{tabular}

a) LaBrecque, A. L. 1964. Costs and returns based on data of the Rockland red pine plantation. Economics Division, Canadian Forestry Service, Ottawa, Ont. (File report). premium cannot be established at this time, the costs of pruning were not included in these analyses because inclusion would have resulted in a cost with no corresponding benefit. The premium required to cover the cost of pruning can be computed, however, by determining the present worth of the cost of pruning and dividing this cost by the volume at the time of harvest. If we assume an interest rate of $6 \%$, for example, the present worth of a $\$ 10.00$-per-acre pruning job done 38 years ago is $\$ 91.54$. The volume of the 158 crop trees, including the 20 - $\mathrm{ft}$ butt logs, is 22,612 fbm (Table 1). The pruning effort could be economical in this case if a premium of $\$ 4.05 / \mathrm{Mfbm}$ were received from the sale of stumpage. If the investor wanted $8 \%$ on his money, the premium would be $\$ 8.24$. These calculations assume that the final harvest takes place in 1976 . The premium that must be realized at any future date will be higher or lower depending on whether the volume increase is greater or less than the assumed acceptable rate of interest. 


\section{Net Present Worth}

The net present worth of the ten alternatives was computed at 4, 6, 8 and $10 \%$ (Table 6). The results show that positive net present worth is realized at 4,6 , and $8 \%$ in both the thinned stand and the control as long as clearcutting is delayed until the plantation is 37 years old. Alternatives terminating in the 24th year and all alternatives discounted at $10 \%$ resulted in a negative net present worth. In the three longest rotations, thinning alternatives provided greater returns than non-thinning alternatives during the same period. An interesting observation of this analysis is that at 4 and $6 \%$ discount rates, the highest return occurred in alternatives terminating in year 57 while at 8 and $10 \%$ the greatest return or least loss was realized in alternatives ending in years 47 or 37 . This illustrates the fact that the higher the interest rate the shorter the economic rotation.

\section{Current Costs and Returns}

Because of the erratic increase in cost and product values during the past 50 years, an analysis that assumed stable prices was carried out in an attempt to isolate the economic effects of physical change that were due to the thinning program. In this analysis, estimates of current costs and revenues (Table 7) were multiplied by merchantable cubic foot volumes (Table 1) and volumes of harvested pulpwood, sawlogs and poles (Table 2) to derive costs and revenues in current dollars (Table 8 ).

\section{Net Present Worth}

The net present worth was computed for each of the ten hypothetical alternatives at 4, 6 and $8 \%$ (Table 9). Examination of the calculations shows that the alternatives did not generate enough positive cash flow to earn an $8 \%$ return on the capital invested. However, all alternatives with the exception of 1 and 6 were positive at $6 \%$. In evaluating these rates it must be kept in mind that they are non-inflationary returns to capital. With an inflation rate of $6 \%$, the total rate realized would be more than $12 \%$ in alternatives which, according to the table, earn $6 \%$ or more.

The analysis also shows that investment in thinning is not as attractive as investment in planting and clearcutting. The evidence is not conclusive, however, because the differences are not great. It appears that the major problem was the non-commercial thinning which occurred during the 24th year. If this thinning could have been delayed until it became less expensive or even paid for itself, a thinning program would have been more attractive, pro-

Table 5. Costs per acre of plantation establishment and logging, and revenues received from the sale of different products in actual or estimated dollars by age of stand and type of cut

\begin{tabular}{|c|c|c|c|c|c|c|}
\hline \multirow[b]{2}{*}{ Alternatives } & \multirow{2}{*}{$\begin{array}{l}\text { Age of } \\
\text { stand }\end{array}$} & \multirow[b]{2}{*}{ Activity } & \multirow[b]{2}{*}{ Costs } & \multicolumn{3}{|c|}{ Product values } \\
\hline & & & & Poles & Sawlog & Pulp \\
\hline & & & & & hinned stan & \\
\hline$(1) \ldots \ldots \ldots \ldots \ldots \ldots \ldots \ldots \ldots \ldots$ & $\begin{array}{r}0 \\
24\end{array}$ & $\begin{array}{l}\text { plant } \\
\text { clearcut }\end{array}$ & $\begin{array}{l}10.00 \\
67.61\end{array}$ & - & 10.42 & 46.40 \\
\hline$(2) \ldots \ldots \ldots \ldots \ldots \ldots \ldots \ldots \ldots \ldots \ldots$ & $\begin{array}{r}0 \\
24 \\
37\end{array}$ & $\begin{array}{l}\text { plant } \\
\text { thin } \\
\text { clearcut }\end{array}$ & $\begin{array}{r}10.00 \\
20.33 \\
562.87\end{array}$ & 510.12 & $\begin{array}{r}.63 \\
208.60\end{array}$ & $\begin{array}{r}11.00 \\
187.20\end{array}$ \\
\hline (3) $\ldots \ldots \ldots \ldots \ldots \ldots \ldots \ldots \ldots \ldots \ldots \ldots$ & $\begin{array}{r}0 \\
24 \\
37 \\
47\end{array}$ & $\begin{array}{l}\text { plant } \\
\text { thin } \\
\text { thin } \\
\text { clearcut }\end{array}$ & $\begin{array}{r}10.00 \\
20.33 \\
141.29 \\
1,237.64\end{array}$ & $\begin{array}{r}130.24 \\
1,597.86\end{array}$ & $\begin{array}{r}.63 \\
22.88 \\
198.69\end{array}$ & $\begin{array}{r}11.00 \\
31.20 \\
181.20\end{array}$ \\
\hline$(4) \ldots \ldots \ldots \ldots \ldots \ldots \ldots \ldots \ldots \ldots \ldots$ & $\begin{array}{r}0 \\
24 \\
37 \\
47 \\
57\end{array}$ & $\begin{array}{l}\text { plant } \\
\text { thin } \\
\text { thin } \\
\text { thin } \\
\text { clearcut }\end{array}$ & $\begin{array}{r}10.00 \\
20.33 \\
141.29 \\
240.00 \\
1,590.00\end{array}$ & $\begin{array}{r}130.24 \\
222.04 \\
2,173.50\end{array}$ & $\begin{array}{r}.63 \\
22.88 \\
33.43 \\
479.52\end{array}$ & $\begin{array}{r}11.00 \\
31.20 \\
50.40 \\
280.80\end{array}$ \\
\hline (5)... & $\begin{array}{r}0 \\
24 \\
37 \\
47 \\
57 \\
62\end{array}$ & $\begin{array}{l}\text { plant } \\
\text { thin } \\
\text { thin } \\
\text { thin } \\
\text { thin } \\
\text { clearcut }\end{array}$ & $\begin{array}{r}10.00 \\
20.33 \\
141.29 \\
240.00 \\
622.50 \\
1,356.00\end{array}$ & $\begin{array}{r}130.24 \\
222.04 \\
735.08 \\
1,703.52\end{array}$ & $\begin{array}{r}.63 \\
22.88 \\
33.43 \\
170.77 \\
501.50\end{array}$ & $\begin{array}{r}11.00 \\
31.20 \\
50.40 \\
136.80 \\
215.60\end{array}$ \\
\hline & & & & & Control stan & \\
\hline$(6) \ldots \ldots \ldots \ldots \ldots \ldots \ldots \ldots \ldots \ldots \ldots \ldots$ & $\begin{array}{r}0 \\
24\end{array}$ & $\begin{array}{l}\text { plant } \\
\text { clearcut }\end{array}$ & $\begin{array}{l}10.00 \\
66.62\end{array}$ & & 14.67 & 42.20 \\
\hline$(7) \ldots \ldots \ldots \ldots \ldots \ldots \ldots \ldots \ldots$ & $\begin{array}{r}0 \\
37\end{array}$ & $\begin{array}{l}\text { plant } \\
\text { clearcut }\end{array}$ & $\begin{array}{r}10.00 \\
542.94\end{array}$ & 386.88 & 255.85 & 226.80 \\
\hline$(8) \ldots \ldots \ldots \ldots \ldots \ldots$ & $\begin{array}{r}0 \\
47\end{array}$ & $\begin{array}{l}\text { plant } \\
\text { clearcut }\end{array}$ & $\begin{array}{r}10.00 \\
1,390.42\end{array}$ & $1,441.26$ & 322.42 & 289.80 \\
\hline$(9) \ldots \ldots \ldots \ldots \ldots \ldots \ldots \ldots \ldots \ldots \ldots$ & $\begin{array}{r}0 \\
57\end{array}$ & $\begin{array}{l}\text { plant } \\
\text { clearcut }\end{array}$ & $\begin{array}{r}10.00 \\
1,777.50\end{array}$ & $2,000.60$ & 634.92 & 513.60 \\
\hline$(10) \ldots \ldots \ldots \ldots \ldots \ldots \ldots \ldots \ldots \ldots$ & $\begin{array}{r}0 \\
62\end{array}$ & $\begin{array}{l}\text { plant } \\
\text { clearcut }\end{array}$ & $\begin{array}{r}10.00 \\
2,451.00\end{array}$ & $2,286.18$ & 986.34 & 641.20 \\
\hline
\end{tabular}


Table 6. Net present worth of the ten management alternatives shown in Table 5 computed at four rates of interest.

\begin{tabular}{crrrr}
\hline & \multicolumn{5}{c}{ Discount rate } \\
\cline { 2 - 5 } Alternatives & \multicolumn{1}{c}{$\mathbf{4}$} & $\mathbf{6}$ & \multicolumn{1}{c}{$\mathbf{8}$} & \multicolumn{1}{c}{$\mathbf{1 0}$} \\
\hline & & \multicolumn{3}{c}{ Thinned stand } \\
1 & -23.30 & -16.81 & -13.89 & -12.34 \\
2 & 87.49 & 31.18 & 9.04 & -.81 \\
3 & 135.35 & 43.53 & 11.32 & -1.30 \\
4 & 168.88 & 47.32 & 9.74 & -3.00 \\
5 & 159.65 & 42.12 & 7.20 & -4.14 \\
& & & & \\
& & Control stand & \\
6 & -22.62 & -16.48 & -13.69 & -12.23 \\
7 & 86.87 & 31.46 & 9.49 & -.41 \\
8 & 112.81 & 35.14 & 8.03 & -2.51 \\
9 & 153.03 & 41.10 & 7.15 & -4.02 \\
10 & 129.98 & 30.28 & 2.40 & -6.05 \\
& & & & \\
\hline
\end{tabular}

Table 7. Estimated current costs and revenues.

Value of products at roadside.

Pulp

Sawlogs

Poles

$\$ 28.00$ per cord

$\$ 85.00$ per Mfbm

Cost per acre of planting, thinning and clearcutting.

Planting

Thinning

Clearcutting

$\$ 54.00$ per acre

$\$ .50$ per merchantable $\mathrm{ft}^{3}$

$\$ .25$ per merchantable $\mathrm{ft}^{3}$ vided that the change in physical response was not altered sufficiently to cancel gains.

Another interesting fact to note is that financial maturity at 4 and $6 \%$ is highest in year 47 in both thinned and control stands. This means that although physical growth continues, financial growth peaks at about 50 years. The optimum year of clearcutting, however, may not be the year at which value is the greatest. An investor who has an alternative rate of return of $6 \%$ should clearcut at the point where growth drops to this value, which accrues at approx-

Table 9. Net present worth of the ten management alternatives computed at different rates of interest

\begin{tabular}{crcc}
\hline & \multicolumn{3}{c}{ Discount rate } \\
\cline { 2 - 3 } Alternatives & \multicolumn{1}{c}{$\mathbf{4}$} & $\mathbf{6}$ & $\mathbf{8}$ \\
\hline & & Thinned stand \\
\cline { 2 - 3 } 1 & 34.04 & -8.47 & -28.29 \\
2 & 195.77 & 47.85 & -8.42 \\
3 & 247.84 & 50.28 & -15.87 \\
4 & 177.78 & 11.30 & -36.21 \\
5 & 103.30 & 12.86 & -44.61 \\
& & Control stand & \\
& & & \\
& 27.09 & -12.42 & -30.26 \\
7 & 208.80 & 58.04 & -1.34 \\
8 & 269.47 & 64.91 & -6.52 \\
9 & 186.61 & 22.21 & -28.37 \\
10 & 150.68 & 4.90 & -35.86 \\
\hline
\end{tabular}

Table 8. Costs per acre of plantation establishment and logging, and revenues received from the sale of different products, in current dollars, by stand age and type of cut.

\begin{tabular}{|c|c|c|c|c|c|c|}
\hline \multirow[b]{2}{*}{ Alternatives } & \multirow{2}{*}{$\begin{array}{l}\text { Age of } \\
\text { stand }\end{array}$} & \multirow[b]{2}{*}{ Activity } & \multirow[b]{2}{*}{ Costs } & \multicolumn{3}{|c|}{ Thinned stand } \\
\hline & & & & Poles & Sawlogs & Pulp \\
\hline$\ldots \ldots \ldots$ & $\begin{array}{r}0 \\
24\end{array}$ & $\begin{array}{l}\text { plant } \\
\text { clearcut }\end{array}$ & $\begin{array}{l}54.00 \\
587.25\end{array}$ & & 126.48 & 652.40 \\
\hline (2). & $\begin{array}{r}0 \\
24 \\
37\end{array}$ & $\begin{array}{l}\text { plant } \\
\text { thin } \\
\text { clearcut }\end{array}$ & $\begin{array}{r}54.00 \\
244.00 \\
956.25\end{array}$ & 1020.24 & $\begin{array}{r}7.65 \\
506.60\end{array}$ & $\begin{array}{l}154.00 \\
436.80\end{array}$ \\
\hline (3).. & $\begin{array}{r}0 \\
24 \\
37 \\
47\end{array}$ & $\begin{array}{l}\text { plant } \\
\text { thin } \\
\text { thin } \\
\text { clearcut }\end{array}$ & $\begin{array}{r}54.00 \\
224.00 \\
359.50 \\
1176.00\end{array}$ & $\begin{array}{r}274.56 \\
2308.02\end{array}$ & $\begin{array}{r}7.65 \\
60.78 \\
375.28\end{array}$ & $\begin{array}{r}154.00 \\
72.80 \\
282.80\end{array}$ \\
\hline (4). & $\begin{array}{r}0 \\
24 \\
37 \\
47 \\
57\end{array}$ & $\begin{array}{l}\text { plant } \\
\text { thin } \\
\text { thin } \\
\text { thin } \\
\text { clearcut }\end{array}$ & $\begin{array}{r}54.00 \\
224.00 \\
359.50 \\
408.00 \\
1351.25\end{array}$ & $\begin{array}{r}274.56 \\
333.06 \\
2421.90\end{array}$ & $\begin{array}{r}7.65 \\
60.78 \\
67.66 \\
679.32\end{array}$ & $\begin{array}{r}154.00 \\
72.80 \\
78.40 \\
327.60\end{array}$ \\
\hline (5)... & $\begin{array}{r}0 \\
24 \\
37 \\
47 \\
57 \\
62\end{array}$ & $\begin{array}{l}\text { plant } \\
\text { thin } \\
\text { thin } \\
\text { thin } \\
\text { thin } \\
\text { clearcut }\end{array}$ & $\begin{array}{r}54.00 \\
224.00 \\
359.50 \\
408.00 \\
1056.50 \\
959.75\end{array}$ & $\begin{array}{r}274.56 \\
333,06 \\
843.18 \\
1703.52\end{array}$ & $\begin{array}{r}7.65 \\
60.78 \\
67.66 \\
254.66 \\
501.50\end{array}$ & $\begin{array}{r}154.00 \\
72.80 \\
78.40 \\
159.60 \\
215.60\end{array}$ \\
\hline (6) $\ldots \ldots \ldots$ & $\begin{array}{r}0 \\
24\end{array}$ & $\begin{array}{l}\text { plant } \\
\text { clearcut }\end{array}$ & $\begin{array}{r}54.00 \\
591.00\end{array}$ & & 178.16 & 593.60 \\
\hline (7)... & $\begin{array}{r}0 \\
37\end{array}$ & $\begin{array}{l}\text { plant } \\
\text { clearcut }\end{array}$ & $\begin{array}{r}54.00 \\
1014.75\end{array}$ & 773.76 & 621.35 & 529.20 \\
\hline (8). & $\begin{array}{r}0 \\
47\end{array}$ & $\begin{array}{l}\text { plant } \\
\text { clearcut }\end{array}$ & $\begin{array}{r}54.00 \\
1367.50\end{array}$ & 2081.82 & 609.03 & 450.80 \\
\hline (9) $\ldots \ldots \ldots$ & $\begin{array}{r}0 \\
57\end{array}$ & $\begin{array}{l}\text { plant } \\
\text { clearcut }\end{array}$ & $\begin{array}{r}54.00 \\
1639.25\end{array}$ & 2229.24 & 899.47 & 599.20 \\
\hline$\ldots \ldots \ldots \ldots \ldots \ldots$ & $\begin{array}{r}0 \\
62\end{array}$ & $\begin{array}{l}\text { plant } \\
\text { clearcut }\end{array}$ & $\begin{array}{r}54.00 \\
1735.50\end{array}$ & 2286.18 & 986.34 & 641.20 \\
\hline
\end{tabular}


imately 50 years. An investor who is satisfied with a $4 \%$ return may find a longer rotation satisfactory.

\section{Conclusions}

The implications of an economic analysis of a case study depend upon the investor, his needs, his wants and his alternatives. The conclusions are dependent upon assumptions of costs and returns. This study illustrates the physical response to a thinning program and the economic results calculated on the basis of historical and assumed costs and revenues. On the basis of historical costs, the investment looked attractive and the thinning program increased net present worth at each stage. On the basis of current costs and revenues, with no increase at an assumed inflation rate, the investments did not appear as attractive, there was no conclusive proof that the thinning program would be profitable, and financial growth peaked at a rotation length of approximately 50 years.

Is this contradictory? Not really. In the first case, revenues increased substantially more than costs, and because of inflation the attractiveness of these investments in terms of real dollars is not as great as it appears. The return in the second analysis is a net return after inflation because stable costs and revenues are assumed. Therefore, in a period of $6 \%$ inflation, a $10 \%$ return in the first analysis is not as attractive as a $5 \%$ return in the second.

\section{Acknowledgements}

The authors gratefully acknowledge the cooperation and wholehearted support received from the owner (from 1922-1972) of the plantation, the late Mr. S. H. Morris, who took great pride in his plantation and in the work reported here. Without his help the study would not have been possible. Thanks are due Mr. F. Evert, Canadian Forestry Service, for invaluable advice concerning the analysis of stand growth; to Mr. Barry Warwick, Ontario Ministry of Natural Resources; and to Mr. L. Delorme, Plantagenet, Ontario for information on operational costs and product prices.

\section{References}

Anon. 1948. Form-class volume tables. Can, Dep. Mines Resour., Mines For. Sci. Br., Domin. For. Serv. (2nd ed.).

Anon. 1960. Specifications for the physical properties of jack, lodgepole and red pine poles and reinforcing stubs. Can. Standards Assoc., Ottawa, Ont. (3rd ed.).

Mulloy, G. A. 1943. Growth of red pine plantations under management. Can. Dep. Mines Resour., Domin. For. Serv., Silvic. Leafl. No. 17.

Mulloy, G. A. 1946. Thinning red pine, Rockland, Ontario (1943). Can. Dep. Mines Resour., Domin. For. Serv., Silvic. Res. Note No. 79.

Sisam, J. W. B. 1939. Thinning and pruning experiment, red pine plantation, Rockland, Ontario. Can. Dep. Mines Resour., Domin. For. Serv., Silvic. Res. Note No. 57.

Stiell, W. M. 1953. Thinning and growth in a red pine plantation. Can. Dep. Resour. Devel., For. Br., Div. For. Res. Silvic. Leafl. No. 75.

Stiell, W. M. 1957. The Rockland red pine plantation. Timber Can. April 1957.

von Althen, F. W. and W. M. Stiell. 1965. Twenty-three years of management in the Rockland red pine plantation. Dep. For., Ottawa, Ont. Publ. No. 1123.

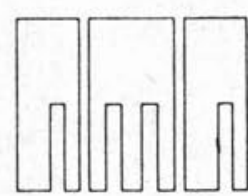

\section{Alan Moss \& Associates Ltd.}

Consultants in Forestry and Forest Industries

\section{Domestic and International}

\author{
1334 St. Paul Street
}

Kelowna, British Columbia V1Y 2E1

Telephone: (604) 763-4811

Cable: Sylva

\section{Woodlot Service Ltd.}

"All Matters Pertaining to Forestry"

\author{
GORDON B. YOUNG, B.Sc.F., M.F.
}

Registered Professional Forester 